\title{
Higher IGFBP-1 to IGF-1 serum ratio predicts unfavourable survival in patients with nasopharyngeal carcinoma
}

\author{
Xinwei Feng ${ }^{1+}$, Jianhua Lin ${ }^{2 \dagger}$, Shan Xing ${ }^{2}$, Wanli Liu² and Ge Zhang ${ }^{1 *}$
}

\begin{abstract}
Background: The insulin-like growth factor (IGF) system plays an important role in the development and progression of cancer. However, little is known about the expression of the IGF system components and their clinicopathological significance and prognostic value in nasopharyngeal carcinoma (NPC).

Methods: IGF system components (IGF-1, IGF-2, IGF-1SR, IGFBP-1, IGFBP-2, IGFBP-3, IGFBP-4 and IGFBP-6) were quantified from the plasma of NPC patients and healthy individuals using the RayBio Human Cytokine Antibody Array. IGFBP-1 and IGF-1 mRNA levels were quantified by real-time qPCR, and protein expression was detected by western blot in nine NPC cell lines and four immortalized nasopharyngeal epithelial (NPE) cell lines. Tissue-specific expression of IGFBP-1 and IGF-1 was detected by immunohistochemistry in paraffin-embedded NPC tissues. ELISA analysis was used to measure the serum levels of IGFBP-1 and IGF-1 in 142 NPC patients and 128 healthy controls and determine potential correlation with clinicopathological parameters.
\end{abstract}

Results: Significantly higher levels of circulating IGFBP-1 and lower levels of IGF-1 and IGF-2 were detected in NPC patients compared to healthy controls by Cytokine Antibody Array analyses ( $P=0.034,0.012,0.046$, respectively). IGFBP-1 expression was detected in the majority of NPC cell lines, but not in NPE cell lines, and was shown to localize to the nucleus of tumour cells, in contrast to the cytoplasmic staining observed in normal cells. Importantly, IGFBP-1 expression was stronger in NPC tumour tissues compared to peritumoural tissues. In contrast, IGF-1 expression was weak or absent in NPC and NPE cell lines, with the exception of the EBV-infected C666 cell line, and was found to be expressed at lower levels in tumour tissues compared to tumour-adjacent normal tissue. Levels of serum IGFBP-1 were shown to be significantly higher in patients with NPCs compared to healthy control individuals $(55.23 \pm 41.25 \mu \mathrm{g} / \mathrm{L}$ vs. $32.08 \pm 29.73 \mu \mathrm{g} / \mathrm{L}, P<0.001$ ), whereas serum levels of IGF-1 were significantly lower in NPC patients compared to healthy controls $(98.14 \pm 71.48 \mu \mathrm{g} / \mathrm{L}$ vs. $164.01 \pm 92.08 \mu \mathrm{g} / \mathrm{L}, P=0.001)$. Consistently, the IGFBP-1/IGF-1 serum ratio was shown to be significantly higher in NPC patients compared to healthy control individuals $(P=0.002)$. Serum levels of IGFBP-1 and the IGFBP-1/IGF-1 ratio significantly correlated with age $(P=0.020 ; P=0.016)$, WHO histological classification ( $P=0.044 ; P=0.048)$, titre of EA (EB Virus Capsid Antigen-IgA) and NPC $(P=0.015 ; P=0.016)$. In contrast, higher IGFBP-1 serum levels and IGFBP-1/IGF-1 ratio significantly correlated with poor RFS $(P=0.046 ; P=0.037)$ and OS $(P=0.038 ; P=0.009)$. Multivariate analysis revealed that the IGFBP-1/IGF-1 ratio, but not serum IGFBP-1 level, represents an independent risk factor for poor RFS $(P=0.044)$ and OS $(P=0.035)$.

Conclusions: A higher IGFBP-1/IGF-1 serum ratio is significantly associated with poor prognosis in NPC patients.

Keywords: Insulin-like growth factor binding protein 1, Insulin-like growth factor 1, Nasopharyngeal carcinoma, Clinical prognosis

\footnotetext{
* Correspondence: zhangge@mail.sysu.edu.cn

†'Equal contributors

'Department of Microbial and Biochemical Pharmacy, School of

Pharmaceutical Sciences, Sun Yat-sen University, No.132 Waihuandong Road,

University Town, Guangzhou 510006, China

Full list of author information is available at the end of the article
} 


\section{Background}

Nasopharyngeal carcinoma (NPC) is a malignant head and neck tumour with a distinct racial and geographical distribution that is highly prevalent in Southeast Asia [1]. Although radiotherapy and chemotherapy are efficient therapeutic approaches for treating NPC, the disease remains a deadly due to late presentation of the disease and poor prognosis. Because NPC tumours are asymptomatic, advanced disease at time of diagnosis and high rates of recurrence and metastasis underlie the high mortality rate in NPC patients. Therefore, finding new biomarkers or risk factors will contribute to earlier diagnosis and better prognosis for NPC patients.

The insulin-like growth factor (IGF) system consists of a complex network of ligands (IGF-1 and 2), their cognate receptors (IGFR-1 and 2), IGF-binding proteins (IGFBP1-6), and IGFBP proteases. The IGF signalling pathway, which facilitates communication between cells and their physiologic environment, may be involved in human cancer progression and can be targeted for therapeutic intervention [2]. Within the blood stream, IGF-1 is bound to IGFBPs and activates IGF-1R following its release from the complex. The interaction between IGFs, IGFBPs and IGFRs promotes cellular proliferation and inhibits apoptosis [3].

Several studies have reported a correlation between circulating levels of IGF-1 and IGFBP-1 in healthy people and the risk of cancer development. IGF-1 plasma or serum levels have been reported to be increased in patients with a variety of cancers, including colorectal adenoma, malignant melanoma, breast cancer, non-small cell lung cancer [4-6]. However, conflicting results have been observed in studies conducted in prostate cancer, epithelial ovarian cancer, breast cancer, and oral cancer [7-10]. In addition, serum levels of IGFBP-1 have been reported to be increased in metastatic prostate and oral cancers, but not in pancreatic, non-metastatic colorectal or endometrial cancers [11-13]. Despite considerable research, the role of IGFs in cancer remains unclear, and clinical trials have been unsuccessful [14]. Moreover, how IGF-1 and IGFBP-1 are regulated at the expression level remains equivocal in tumour tissues and within the circulating blood stream.

In the present study, we examined the expression patterns of IGF-1 and IGFBP-1 in different NPC and normal nasopharyngeal epithelial (NPE) cells lines. Furthermore, we assessed the serum levels of IGF-1 and IGFBP-1 in NPC patients and healthy control individuals and determined whether altered IGF-1 and IGFBP-1 levels were associated with clinical outcome to assess the potential value of IGF-1 or IGFBP-1 as a prognostic biomarker for NPC.

\section{Methods}

Patients, blood and tissue samples

Plasma from 10 NPC patients and 10 healthy volunteers were obtained in October 2012 and used for 8 IGFrelated cytokine arrays. Plasma samples were stored at $80{ }^{\circ} \mathrm{C}$ and were measured in 3 months.

Sera used for IGF-1 and IGFBP-1 arrays were obtained from 143 patients with NPC between November 2005 and October 2008. The cohort consisted of 119 male patients and 24 female patients. Patients ranged in age from 15 to 71 years (mean, 49.6 years). All sera and plasma were collected from NPC patients at the time of diagnosis and prior to tumour radiation therapy or surgery. The 143 patient characteristics are described in Table 1.

Table 1 Clinical characteristic of 142 patients with NPC

\begin{tabular}{|c|c|}
\hline Characteristic & No. (\%) \\
\hline \multicolumn{2}{|l|}{ Sex } \\
\hline Male & $118(83)$ \\
\hline Female & $24(17)$ \\
\hline \multicolumn{2}{|l|}{ AGE } \\
\hline Median & 49.6 \\
\hline Range & $15-71$ \\
\hline$\leq 45$ & $73(51)$ \\
\hline$>45$ & $69(49)$ \\
\hline \multicolumn{2}{|l|}{ Follow-up Time } \\
\hline Median (range) & $73(13-125)$ \\
\hline \multicolumn{2}{|l|}{ Tumor Size } \\
\hline $\mathrm{T} 1+\mathrm{T} 2$ & $27(19)$ \\
\hline $\mathrm{T} 3+\mathrm{T} 4$ & $115(81)$ \\
\hline \multicolumn{2}{|c|}{ Lymphoid nodal states } \\
\hline NO-1 & $76(53)$ \\
\hline N2-3 & $66(47)$ \\
\hline \multicolumn{2}{|l|}{ Clinical Stage } \\
\hline $1+2$ & $15(11)$ \\
\hline $3+4$ & $127(89)$ \\
\hline \multicolumn{2}{|c|}{ Local-regional relapse } \\
\hline Yes & $16(11)$ \\
\hline No & $126(89)$ \\
\hline \multicolumn{2}{|l|}{ Metastasis } \\
\hline Yes & $4(3)$ \\
\hline No & $138(97)$ \\
\hline \multicolumn{2}{|c|}{ WHO histological classification } \\
\hline NKUC & $131(92)$ \\
\hline NKDC & $11(8)$ \\
\hline \multicolumn{2}{|l|}{ OS rate (\%) } \\
\hline 5-year & $78.2 \%$ \\
\hline
\end{tabular}


Overall survival (OS) was defined as the interval between the date of surgery and the date of death or the last known follow-up visit. Relapse-free survival (RFS) was defined as the interval between the operation and the date that tumour recurrence or metastasis was diagnosed. All follow-up data from the NPC patients used in this study were available and complete. A total of 31 (21.8\%) patients died during follow-up period.

Sera from 128 healthy volunteers (95 males, 33 females) with ages ranging from 21 to 77 years (mean: 47.8 years) were collected and used as controls. Healthy controls were selected from an archive of blood samples, and the control samples were matched as closely as possible to the NPC group with respect to previous handling and the time period of sample collection.

A 5-ml blood sample from each participant was allowed to clot for 30 to $60 \mathrm{~min}$ at room temperature. Each clotted sample was centrifuged at $1500 \mathrm{~g}$ for $10 \mathrm{~min}$. All sera were then aliquoted and frozen at $-80{ }^{\circ} \mathrm{C}$ until use.

Paraffin-embedded tumour tissue samples were obtained from 20 NPC patients who underwent surgery between May and December of 2013. None of the patients had received anticancer treatment prior to surgery, and all of the patients had histologically confirmed primary NPC in this retrospective study.

All of the blood and tissues sample were collected at the Cancer Center of Sun Yat-sen University. The study was approved by the Ethics Committee of Sun Yat-sen University Cancer Center and informed consent was obtained from each patient.

\section{Cytokine array}

Eight IGF system members (IGF-1, IGF-2, IGF-1SR, IGFBP-1, IGFBP-2, IGFBP-3, IGFBP-4 and IGFBP-6) were quantified in the plasma of 10 NPC patients and healthy volunteers using the RayBio Human Cytokine Antibody Array (\#AAH-CYT-5, RayBiotech Inc, GA, USA) according to the manufacturer's instruction.

\section{Cell culture}

Two well-differentiated NPC cell lines CNE1 and HK1, three poorly-differentiated NPC cell lines (CNE2, HONE1, SUNE1) and two SUNE-1 subclones (6-10B and 5-8 F) were cultured in DMEM medium (Sigma, Saint Louis, MO, USA). Two undifferentiated NPC cell lines, C666-1 (EBV-positive) and SUNE2 (extremely low concentrations of EBV), were cultured in RPMI 1640 medium (Sigma). Immortalized nasopharyngeal epithelial (NPE) cell lines (N5-Tert, N5Bmi-1, N2-Bmi-1) and normal NPE cell lines (NP460) were cultured in Keratinocyte-SFM medium (10744-019, Gibco) and used as a control. All of the cell lines were maintained in our laboratory, and all media were supplemented with $10 \%$ foetal bovine serum (Sigma).

\section{RNA preparation and quantitative real-time PCR}

Total RNA was extracted from NPC and nasopharyngeal epithelial cells lines using the Trizol reagent (Invitrogen, USA) according to the manufacturer's instruction. Reverse transcription of total RNA $(2 \mu \mathrm{g})$ was performed using SuperScript II reverse transcriptase (GIBCO BRL, Grand Island, NY, USA). The quantification of target and reference glyceraldehyde-3-phosphate dehydrogenase (GAPDH) genes was performed using the Power SYBR Green qPCR SuperMix-UDG (Invitrogen, USA) on an iCycler (Bio-Rad, Hercules, CA, USA). CT is defined as the cycle at which the fluorescence is determined to be statistically significant above background. The relative mRNA expression was normalized to the expression of GAPDH, which yielded a $2^{-\Delta C T}$ value $\left(\triangle \mathrm{CT}=\mathrm{CT}_{\text {(target gene) }}-\mathrm{CT}_{(\mathrm{GAPDH})}\right)$. All reactions were performed in triplicate in three independent experiments. The primers used for real-time RT-PCR were as follows: IGF-1: forward 5'- GCT CTT CAG TTC GTG TGT GGA -3' and reverse 5'- GCC TCC TTA GAT CAC AGC TCC -3'; IGFBP-1: forward 5'-CTA TGA TGG CTC GAA GGC TC-3 ' and reverse 5 '-CCC ATT CCA AGG GTA GAC G-3'; GAPDH: forward 5'-GCA CCG TCA AGG CTG AG AAC-3' and reverse 5 '-TGG TGA AGA CGC CAG TGG A-3’.

\section{Western blot}

Total protein was extracted using a lysis buffer and protease inhibitor (Beyotime Biotechnology, China). Equivalent protein amounts were denatured in an SDS sample buffer and then were separated by SDS-PAGE and transferred onto polyvinylidene difluoride membrane. After being blocked with 5\% non-fat dry milk in PBS containing $0.05 \%$ Tween-20, the blotted membranes were incubated with anti-human IGF-1 and IGFBP-1 antibodies, (1:5000, 1:1000, respectively, R\&D systems, USA) and then incubated with a secondary antibody (1:5000, Boster, China). GAPDH protein levels were also determined by using the specific antibody (1:1000, Boster, China) as a loading control.

\section{Immunohistochemistry}

Formalin-fixed, paraffin-embedded NPC sections were incubated with a goat polyclonal anti-IGF-1 (1:100, AF291-NA, R\&D, USA) or anti-IGFBP-1 antibody (1:100, AF871, R\&D, USA) overnight at $4{ }^{\circ} \mathrm{C}$. After washing in PBST, the tissue sections were treated with a horseradish peroxidase-conjugated anti-goat secondary antibody (1:1000, Zymed). The tissue sections were then developed with 3-diaminobenzidine tetrahydrochloride for $10 \mathrm{~s}$, followed by counterstaining with 10\% Mayer's 
haematoxylin. The degree of staining was reviewed by two independent observers.

\section{ELISA}

Serum IGF-1 and IGFBP-1 levels were determined by double-antibody sandwich ELISA according to the manufacturer's instructions (DY291, DY871, R\&D systems, USA). Briefly, 96-well microplates were coated with $100 \mu \mathrm{l} /$ well of the capture antibody (mouse anti-human IGF-1 or IGFBP-1, $4.0 \mu \mathrm{g} / \mathrm{ml})$ overnight at $4{ }^{\circ} \mathrm{C}$. After blocking with $3 \% \mathrm{BSA}, 100 \mu \mathrm{l}$ of the test samples (1:100 diluted in 1\% BSA) was added and incubated for $2 \mathrm{~h}$ at room temperature. Subsequently, $100 \mu \mathrm{l} /$ well of the detection antibody (biotinylated goat anti-human IGF-1 $(150 \mathrm{ng} / \mathrm{ml})$ or IGFBP-1(400 $\mathrm{ng} / \mathrm{ml}))$ was added and incubated for $2 \mathrm{~h}$ at room temperature. Next, $100 \mu \mathrm{l} /$ well of Streptavidin-HRP (1:200) was added and incubated for $20 \mathrm{~min}$ at room temperature. Finally, the substrate (tetramethylbenzidine) solution was added, and the reaction was terminated using $2 \mathrm{~N} \mathrm{H}_{2} \mathrm{SO}_{4}$ and read at an OD of $450 \mathrm{~nm}$. Each test included a standard control $(\mathrm{CV}=12 \%)$.

\section{Statistical analysis}

All statistical analyses were carried out using the SPSS 20.0 statistical software package (SPSS Inc., Chicago, IL). The Mann-Whitney $U$ test was used to evaluate the difference in IGF-1 and IGFBP-1 serum levels between NPC patients and healthy controls. Pearson's chi-squared test was used to analyse the association between IGF-1 and IGFBP-1 levels and the observed clinicopathological characteristics of patients with NPC. Survival curves were plotted by the Kaplan-Meier method and compared using the log rank test. The significance of various variables for survival was analysed using the Cox proportional hazards model (univariate and multivariate analysis). $P<0.05$ was considered to be statistically significant in all cases.

\section{Results}

Circulating levels of IGF-related cytokines differ between NPC patients and healthy control individuals

The plasma level of eight members of the IGF system, including IGF ligands (IGF-1 and IGF-2), IGF-1 soluble receptor (IGF-1 sR), and IGF binding protein (IGFBP-1, IGFBP-2, IGFBP-3, IGFBP-4, and IGFBP-6) were detected in healthy controls and patients with NPC ( $n=10$, respectively) using a Human Cytokine Antibody Array (Fig. 1). The levels of IGF-1 and IGF-2 from NPC patients were significantly lower compared to healthy control individuals $(P=0.012, P=0.046$, respectively). Interestingly, while the plasma level of IGFBP-1 from NPC patients was significantly higher than in healthy control volunteers $(P=0.034)$, no significant differences were observed between the plasma levels of the other IGF soluble receptor or binding proteins, including IGF-1SR, IGFBP-2, IGFBP-3, IGFBP-4 or IGFBP-6. Fourthermore, serum level of IGF-1, IGF-2 and IGFBP-1 were analyzed by ELISA in preliminary experiments $(n=24)$, there was no significant difference in serum IGF2 level between NPC patients and health group. Together, these results suggest that NPC patients display increased circulating levels of IGFBP-1 and decreased levels of IGF-1.

\section{Characterization of IGFBP-1 and IGF-1 expression in NPC and NPE cell lines}

Real-time PCR and western blot analysis showed that IGFBP-1 and IGF-1 were differentially expressed at both

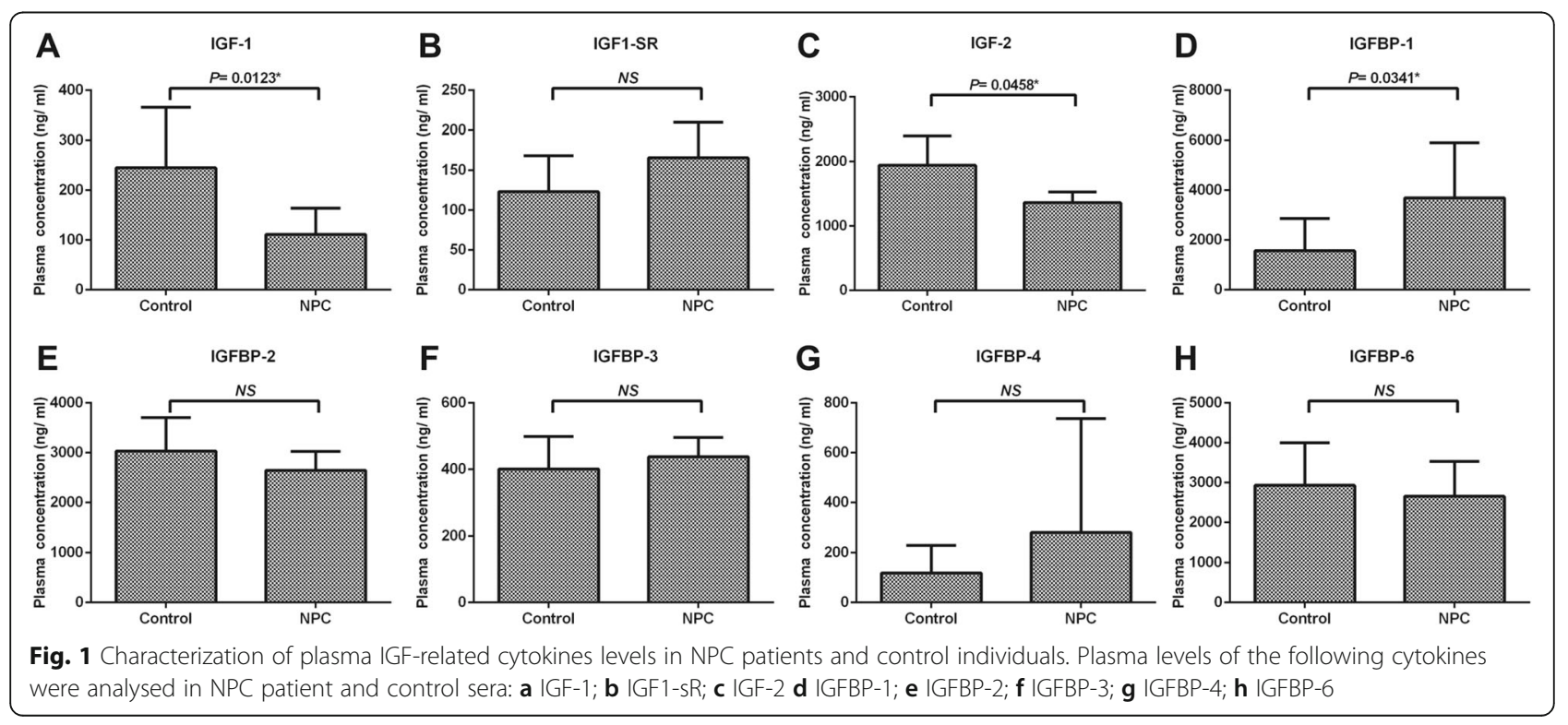


the mRNA and protein level in 9 NPC cell lines (CNE1, CNE2, HONE1, HK1, SUNE1, 6-10B and 5-8 F, C666 and SUNE2) and 4 NPE cell lines (N5-Tert, N5-Bmi1,N2-Bmi-1 and NP460) (Fig. 2a-c). IGFBP-1 mRNA and protein were expressed in most of the NPC cell lines, with the exception of HONE1. CNE1 cells had the highest level of IGFBP-1, and moderate or weaker levels of expression were observed in the other 6 NPC cell lines. However, IGFBP-1 expression was not detected in any of the four NPE cell lines. In addition, ELISA analysis of cell supernatant showed that the secretory level of IGFBP-1 was below the detection limit in most the cell lines, with the exception of CEN1 (Fig. 2c).

IGF-1 mRNA and protein were detected in only 5 NPC cell lines, with the highest expression level of IGF-1 observed in C666 cells, which consistently harbours Epstein-Barr virus (EBV), and weaker expression of IGF-1 detected in three poorly differentiated NPC cell lines (CNE2, 5-F8, SUNE2) and well-differentiated cell lines CNE1. IGF-1 expression was shown to be absent in the other 4 NPC cell lines. Moreover, mRNA and protein levels of IGF-1 were expressed at moderate levels in the immortalized NPE cell line, N5Bmi-1, but not in the other 3 NPE cell lines. ELISA analysis showed that detectable secretory IGF-1 only in C666 cell line.

Those results showed that the stronger expression of IGFBP-1 in tumour cell lines than the normal cell lines, but weak expression of IGF-1 in both of tumour and normal cell lines.

\section{Characterization of IGFBP-1 and IGF-1 expression in NPC tissues}

We examined the expression of IGFBP-1 and IGF-1 in 16 paraffin-embedded archived NPC tissues by immunocytochemistry. IGFBP-1 protein was detected in all of the 16 NPC tumour tissues (100\%) and in 3 of the 16 normal adjacent tissues (18.75\%). Immunostaining of IGFBP-1 was mainly detected in the nuclei of cancer cells and cytoplasm of normal cells, with stronger IGFBP-1 immunostaining present in tumour tissues compared to peritumoural tissues (Fig. 3a-c). In addition, IGF-1 protein was detected in 6 of the 16 NPC tumour tissues $(37.5 \%)$ and in 14 of the 16 tumour-adjacent normal tissues $(87.5 \%)$ with varied IGF-1 immunoreactivity. IGF-1 was shown localize to the cytoplasm of malignant tumour cells and surrounding stromal cells, while stronger cytoplasmic staining of IGF-1 was observed in the normal epithelial and stromal cells of adjacent nontumourous tissue (Fig. 3d-f). Together, these results illustrate that IGFBP-1 is strongly expressed in tumour tissue, while IGF-1 expression is elevated in normal tissue.

\section{Serum levels of IGFBP-1 and IGF-1 correlate with distinct NPC clinicopathological characteristics}

The serum levels of IGFBP-1 and IGF-1 were measured in healthy control individuals $(n=128)$ and NPC patients $(n=142)$, respectively (Fig. 4$)$. The mean concentration of serum IGFBP-1 levels in NPC cases $(55.23 \pm$ $41.25 \mu \mathrm{g} / \mathrm{L}$ ) was significantly higher compared to control

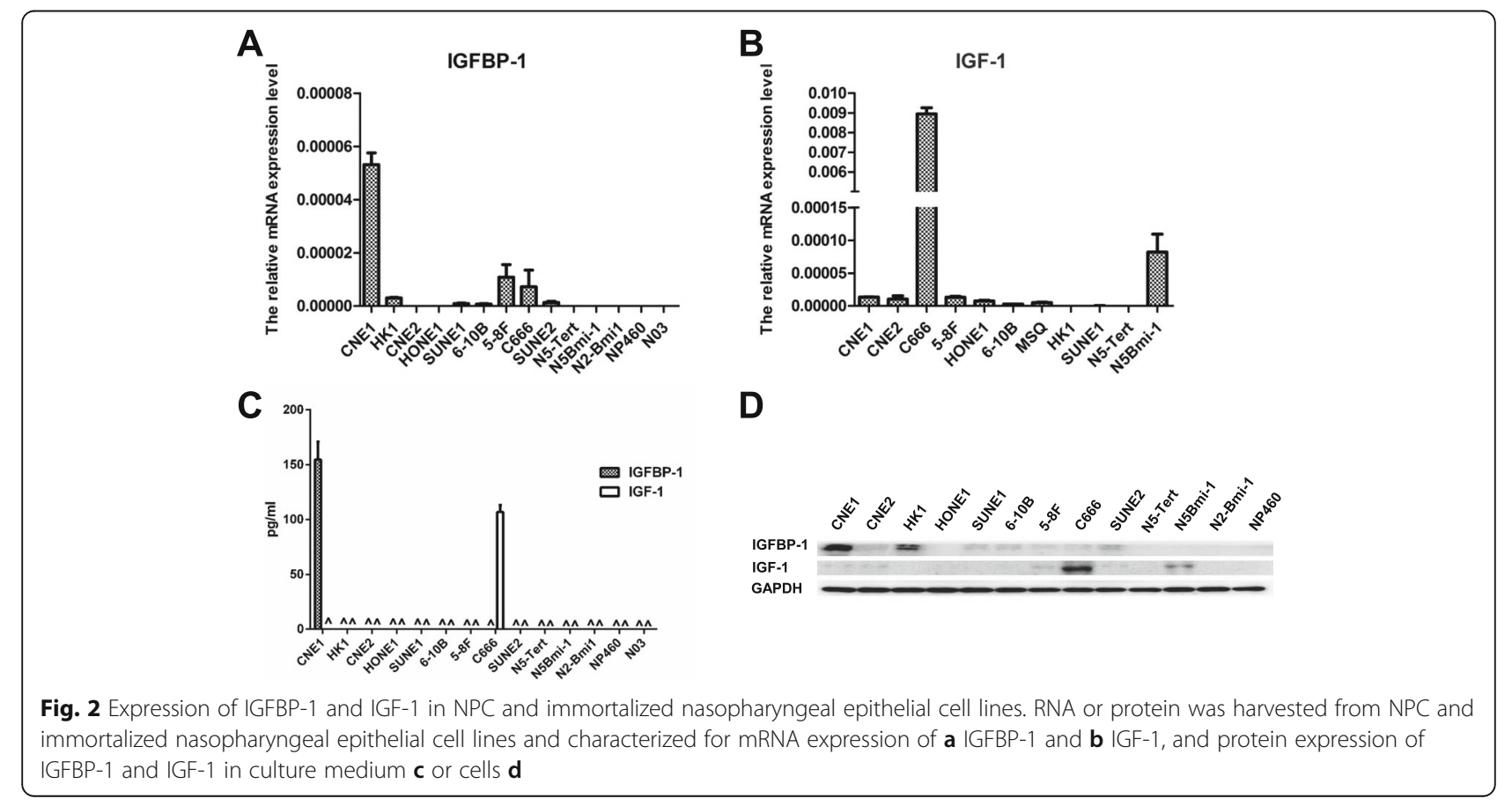



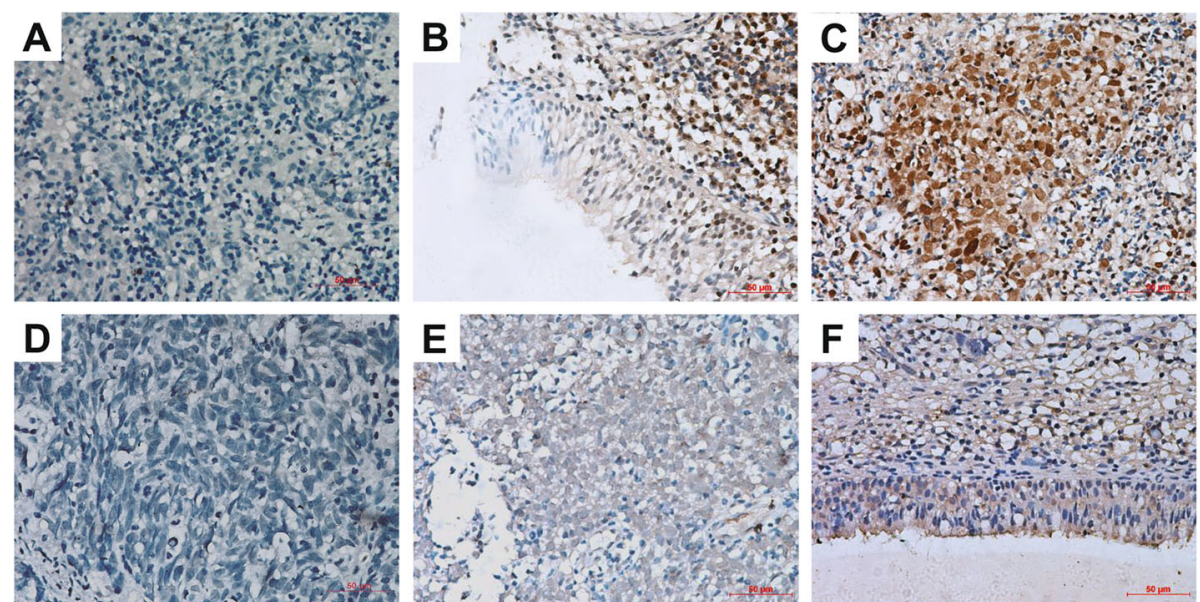

Fig. 3 Expression analysis of IGFBP-1 and IGF-1 in NPC by immunohistochemistry. NPC slides were process for immunohistochemistry of IGFBP-1 and IGF-1 and the following observations were made: a-g. (×200). a Negative stain of IGFBP-1 in NPC tissues. b Low expression level of IGFBP-1 in adjacent non-tumourous tissue. $\mathbf{c}$ High expression level of IGFBP-1 in NPC tissues. $\mathbf{d}$ Negative stain of IGF-1 in NPC tissues. e Low expression of IGF-1 in NPC tissues. $\mathbf{f}$ High expression of IGF-1 in adjacent non-tumourous tissue. Bar, 50 um

cases $(32.08 \pm 29.73 \mu \mathrm{g} / \mathrm{L}, P<0.001)$ (Fig. 4a). In contrast, the mean concentration of serum IGF-1 levels in NPC cases $(98.14 \pm 71.48 \mu \mathrm{g} / \mathrm{L})$ was significantly lower compared to control cases $(164.01 \pm 92.08 \mu \mathrm{g} / \mathrm{L}, P=$ 0.01 ) (Fig. $4 \mathrm{~b}$ ). The ratio of IGFBP-1/IGF-1 in NPC patient serum was shown to be significantly higher compared to control volunteers $(P=0.002)$ (Fig. 4c).

Next, we assessed the potential correlation between serum levels of IGFBP-1, IGF-1 and clinical parameters, including tumour node metastasis (TNM) stage, tumour size, lymphoid nodal states, clinical stage, etc. The level of serum IGFBP-1 significantly correlated with age $(P=$ $0.020)$, WHO histological classification $(P=0.044)$ and titre of EA (EBV early antigen-IgA) of NPC $(P=0.015)$. In addition, IGF-1 serum levels were shown to significantly correlate with gender, but not with other clinical parameters, and the mean level of IGF-1 in female patients was higher than in males $(P=0.018)$. Furthermore, we found that the IGFBP-1/IGF-1 ratio significantly correlated with age $(P=0.016)$, WHO histological classification $(P=0.048)$ and titre of EA of NPC $(P=$ 0.016). Table 2 shows the relationship between clinicopathological data of patients with NPC and the serum levels of IGFBP-1, IGF-1, and IGFBP-1/IGF-1 ratio.

\section{Prognostic significance of serum IGF-1 and IGFBP-1 levels in NPC patients}

Patients were classified into two groups according to their mean IGFBP-1 level $(<55.23 \mu \mathrm{g} / \mathrm{L}$ vs. $\geq 55.23 \mu \mathrm{g} / \mathrm{L})$ and IGFBP-1/IGF-1 ratio (1:1), respectively. The OS and RFS of patients with NPC were plotted using the Kaplan-Meier method, and a log-rank test was employed to evaluate the prognostic significance of IGFBP-1 levels and IGFBP-1/IGF-1ratio. The group with lower IGFBP-1 levels $(<55.23 \mu \mathrm{g} / \mathrm{L})$ displayed a significantly better 5 -year survival rate compared to the group with higher IGFBP-1 levels $(\geq 55.23 \mu \mathrm{g} / \mathrm{L}$; Fig. 5a-b). The cumulative 5-year survival rate in the lower IGFBP-1 group was $87.6 \%$ compared to the $71.4 \%$ rate observed in the higher IGFBP-1 group $(P=0.038)$. Kaplan-

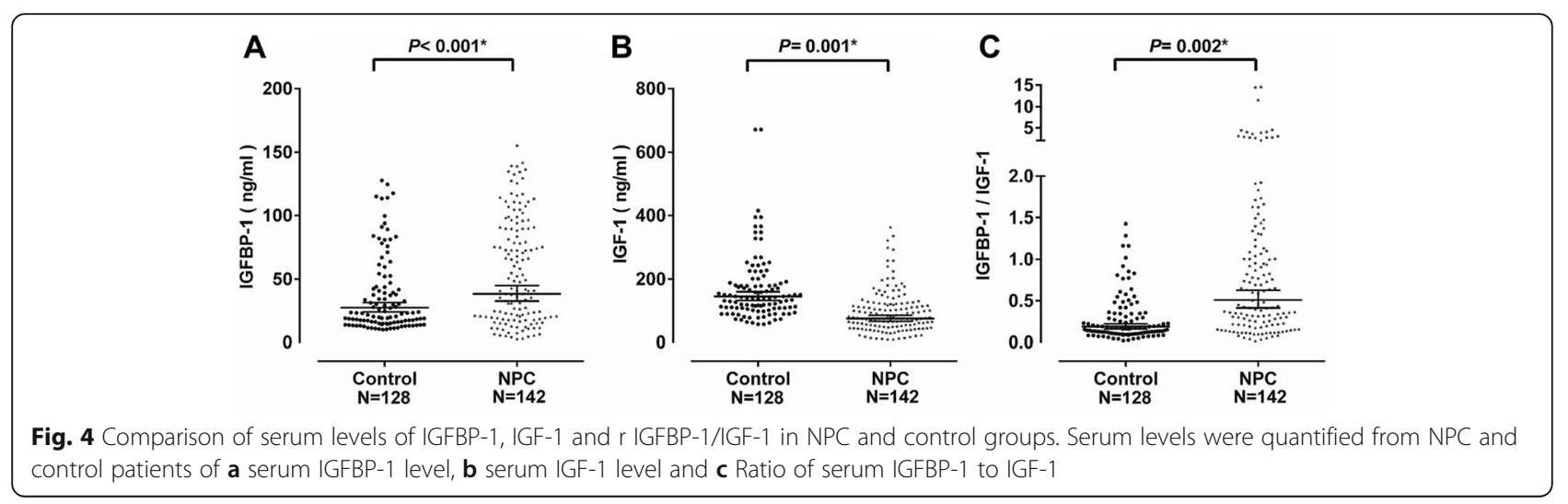


Table 2 Clinicpathological associations of IGF-1 and IGFBP-1 expression levels and IGF-1/IGFBP-1

\begin{tabular}{|c|c|c|c|c|c|c|c|c|}
\hline \multirow[t]{2}{*}{ Variables } & \multirow{2}{*}{$\begin{array}{l}\text { Cases } \\
(n)\end{array}$} & \multirow{2}{*}{$\begin{array}{l}\text { IGFBP-1(ng/L) } \\
(\text { Mean } \pm S D)\end{array}$} & \multirow{2}{*}{$\begin{array}{l}\text { Significance } \\
(P)^{*}\end{array}$} & \multirow{2}{*}{$\begin{array}{l}\text { IGF-1(ng/L) } \\
(\text { Mean } \pm \text { SD) }\end{array}$} & \multirow{2}{*}{$\begin{array}{l}\text { Significance } \\
(P)^{*}\end{array}$} & \multicolumn{2}{|c|}{ IGFBP-1/IGF-1 } & \multirow{2}{*}{$\begin{array}{l}\text { Significance } \\
(P)^{*}\end{array}$} \\
\hline & & & & & & $>1$ & $\leq 1$ & \\
\hline \multicolumn{9}{|l|}{ Gender } \\
\hline Male & 118 & $55.08 \pm 41.66$ & 0.966 & $88.26 \pm 60.75$ & $0.018^{*}$ & 38 & 80 & 0.202 \\
\hline Female & 24 & $55.93 \pm 40.05$ & & $135.98 \pm 88.78$ & & 4 & 20 & \\
\hline \multicolumn{9}{|l|}{ Age (y) } \\
\hline$<46$ & 73 & $47.18 \pm 36.51$ & $0.020^{*}$ & $103.65 \pm 69.31$ & 0.217 & 16 & 57 & $0.016^{*}$ \\
\hline$\geq 46$ & 69 & $63.85 \pm 44.47$ & & $89.02 \pm 66.48$ & & 28 & 41 & \\
\hline \multicolumn{9}{|l|}{ Tumor size } \\
\hline $\mathrm{T} 1+\mathrm{T} 2$ & 27 & $47.54 \pm 36.71$ & 0.260 & $87.09 \pm 55.78$ & 0.437 & 7 & 20 & 0.528 \\
\hline $\mathrm{T} 3+\mathrm{T} 4$ & 115 & $57.01 \pm 42.18$ & & $100.71 \pm 74.63$ & & 37 & 78 & \\
\hline \multicolumn{9}{|c|}{ Lymphoid nodal states } \\
\hline No-1 & 76 & $51.02 \pm 41.80$ & 0.156 & $96.69 \pm 75.17$ & 0.946 & 20 & 56 & 0.197 \\
\hline $\mathrm{N} 2-3$ & 66 & $59.99 \pm 40.41$ & & $99.79 \pm 67.59$ & & 24 & 42 & \\
\hline \multicolumn{9}{|c|}{ Clinical Stage } \\
\hline $1+2$ & 15 & $39.11 \pm 37.45$ & 0.101 & $99.42 \pm 58.73$ & 0.853 & 3 & 12 & 0.498 \\
\hline $3+4$ & 127 & $57.11 \pm 41.40$ & & $97.99 \pm 73.02$ & & 41 & 86 & \\
\hline \multicolumn{9}{|c|}{ Local-regional relapse } \\
\hline Yes & 16 & $49.59 \pm 39.68$ & 0.537 & $117.07 \pm 88.62$ & 0.198 & 4 & 12 & 0.793 \\
\hline No & 126 & $55.94 \pm 41.55$ & & $95.76 \pm 69.08$ & & 40 & 86 & \\
\hline \multicolumn{9}{|l|}{ Metastasis } \\
\hline Yes & 4 & $43.16 \pm 41.80$ & 0.542 & $58.52 \pm 27.71$ & 0.263 & 1 & 3 & 0.775 \\
\hline No & 138 & $55.96 \pm 41.20$ & & $97.42 \pm 68.94$ & & 43 & 95 & \\
\hline \multicolumn{9}{|c|}{ WHO histological classification } \\
\hline NKUC & 131 & $57.05 \pm 41.94$ & $0.044^{*}$ & $98.25 \pm 73.73$ & 0.978 & 44 & 87 & $0.048^{*}$ \\
\hline NKDC & 11 & $38.18 \pm 25.70$ & & $96.88 \pm 36.79$ & & 0 & 11 & \\
\hline \multicolumn{9}{|l|}{ EA } \\
\hline$\leq 1: 10$ & 53 & $44.34 \pm 36.35$ & $0.015^{*}$ & $104.31 \pm 78.59$ & 0.431 & 10 & 43 & $0.016^{*}$ \\
\hline$>1: 10$ & 89 & $61.64 \pm 42.79$ & & $94.51 \pm 67.14$ & & 34 & 55 & \\
\hline \multicolumn{9}{|l|}{ VCA } \\
\hline$\leq 1: 40$ & 14 & $57.45 \pm 43.73$ & 0.860 & $102.20 \pm 50.26$ & 0.736 & 2 & 12 & 0.263 \\
\hline$>1: 40$ & 128 & $55.39 \pm 41.05$ & & $95.68 \pm 70.16$ & & 42 & 86 & \\
\hline
\end{tabular}

${ }^{*} P<0.05$, as determined by Pearson's $X^{2}$ test

Meier survival analysis revealed that higher serum IGFBP-1 levels significantly correlated with adverse RFS $(P=0.046)$ and OS $(P=0.038)$. Serum IGF-1 levels did not correlate with RFS or OS (data not shown). The IGFBP-1/IGF-1 ratio was shown to significant correlate with RFS and OS $(P=0.037, P=0.009$, respectively).

To determine whether IGFBP-1 levels or the IGFBP-1/ IGF-1 ratio could potentially be used as an independent prognostic factor for NPC patient outcome, we performed a multivariate analysis for survival using a multivariate Cox regression model with respect to OS and RFS (Table 3). Gender $(P=0.042 ; P=0.022)$, lymphoid nodal states $(P=0.050 ; P=0.023)$ and local- regional relapse $(P=0.047 ; P<0.001)$, metastasis $(P=$ $0.006 ; P=0.028)$, and the IGFBP- $1 /$ IGF- 1 ratio $(P=$ $0.035 ; P=0.044$ ) significantly correlated with $\mathrm{OS}$ and RFS. Thus, our findings indicate that the ratio of IGFBP-1/IGF-1 represents an independent prognostic factor for NPC outcome.

\section{Discussion}

Here, our study showed that patients with NPC display significantly higher serum levels of IGFBP-1 and significantly lower serum levels of IGF-1 compared to healthy control individuals. Moreover, we observed that higher serum IGFBP-1 levels and an IGFBP-1/IGF-1 ratio significantly correlated with decreased overall survival. 


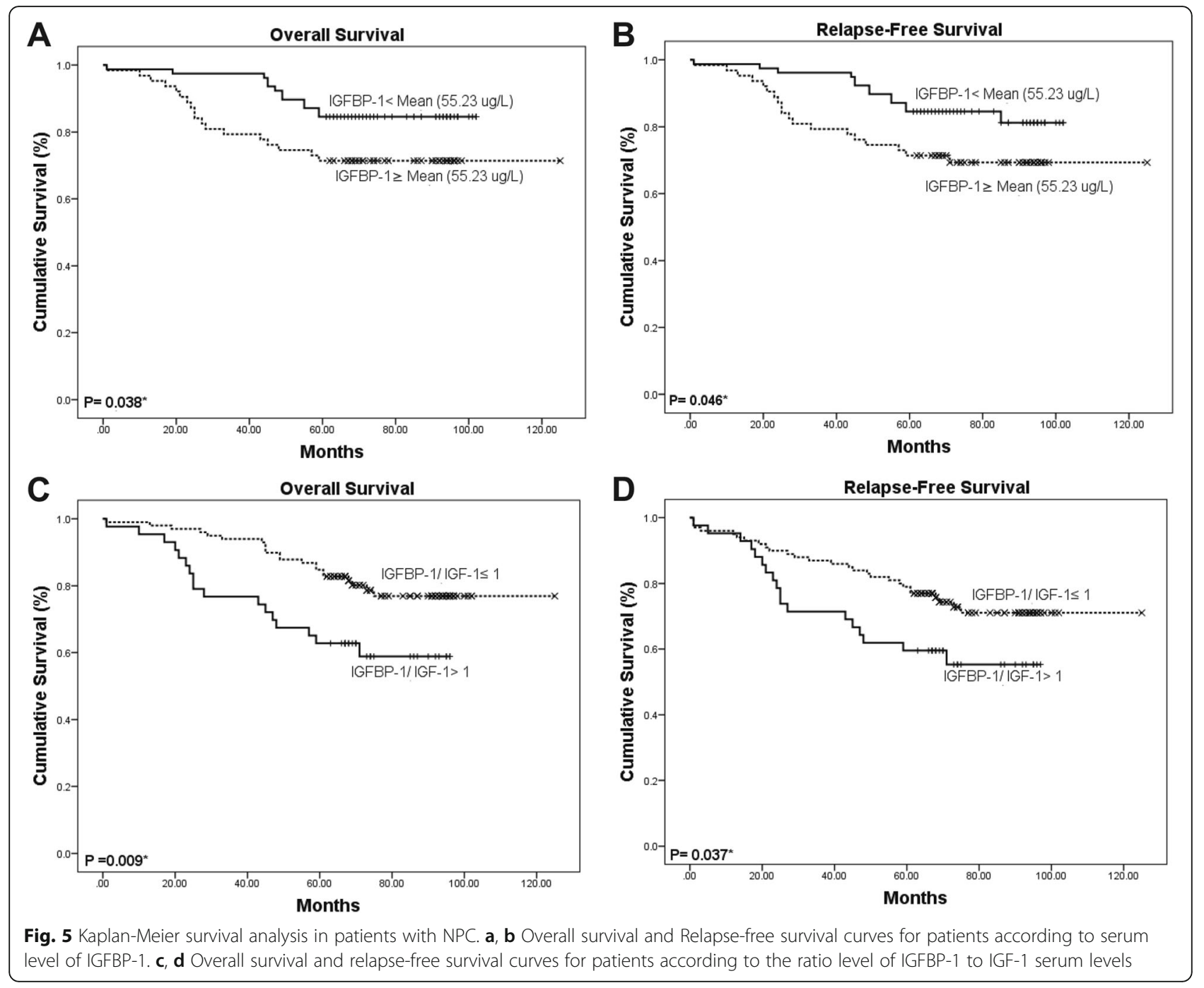

In this study, IGF-1 was more weakly expressed in the majority of nasopharyngeal tumour and normal epithelial cell lines, which is in line with previous studies showing that IGF-1 expression is lower in EBV-negtive NPC cell lines [15]. In addition, IGF-1 expression was also weaker in NPC tumour tissues compared to adjacent normal tissues. Together, these results are consistent with the lower IGF-1 serum levels observed in NPC patients compared to the healthy controls in our study.

Our result that IGF-1 is reduced in NPC patients contradicts those of other studies showing that serum IGF-1 levels are elevated in cancer patients. High serum concentrations of IGF-1 have been associated with an increased risk of breast, prostate, colorectal and HCC $[16,17]$. However, expression of IGF-1 appears to be inconsistent across different types of tumours. For example, IGF-1 protein expression has not been detected in the serum of patients with adrenocortical carcinoma [18], and IGF-1 mRNA levels are weak or absent in oesophageal squamous cell carcinoma cell lines [19]. Moreover, no alterations in IGF-1 mRNA levels are found in head and neck squamous cell carcinoma (HNSCC) [20]. However, in line with our findings, lower serum levels of IGF-1 have been reported in oral cancer patients compared to healthy controls [14]. In addition, reduced IGF-1 serum levels have been reported in epithelial ovarian cancer [21] and lower IGF1 mRNA levels have been observed in HCC compared to corresponding non-malignant liver tissues [22]. Thus, it is possible that serum levels of IGF-1 are dependent on the type of tumour, as well as the local release ratio of IGF-1.

Although IGF-1 functions as an epithelial cell mitogen and has been in implicated in cancer development [23], increased IGF-1 levels have not been associated with tumour malignancy in some models. For example, hepatic IGF-I-deficient mice with reduced circulating IGF-I levels showed a reduced incidence of colon and breast 
Table 3 Multivariate Cox regression analysis for OS of 142 patients with NPC

\begin{tabular}{|c|c|c|c|c|c|c|}
\hline \multirow[t]{2}{*}{ Characteristic } & \multicolumn{3}{|c|}{ Overall Survival } & \multicolumn{3}{|c|}{ Relapse-Free Survival } \\
\hline & $\overline{H R}$ & $95 \% \mathrm{Cl}$ & $P$ value & $\overline{\mathrm{HR}}$ & $95 \% \mathrm{Cl}$ & $P$ value \\
\hline \multicolumn{7}{|l|}{ Gender } \\
\hline Male vs. Female & 0.225 & $0.053-0.950$ & $0.042^{*}$ & 0.247 & $0.075-0.819$ & $0.022^{*}$ \\
\hline \multicolumn{7}{|l|}{ Age (y) } \\
\hline$<46$ vs. $\geq 46$ & 1.389 & $0.673-2.867$ & 0.374 & 2.099 & $1.027-4.293$ & $0.042^{*}$ \\
\hline \multicolumn{7}{|l|}{ Tumor size } \\
\hline $\mathrm{T} 1+\mathrm{T} 2$ vs. $\mathrm{T} 3+\mathrm{T} 4$ & 0.873 & $0.292-2.611$ & 0.809 & 0.972 & $0.325-2.905$ & 0.959 \\
\hline \multicolumn{7}{|l|}{ Lymphoid nodal states } \\
\hline N0-1 vs. N2-3 & 2.312 & $0.969-5.519$ & $0.050^{*}$ & 2.662 & $1.146-6.187$ & $0.023^{*}$ \\
\hline \multicolumn{7}{|l|}{ Clinical Stage } \\
\hline $1+2$ vs. $3+4$ & 0.798 & $0.327-1.945$ & 0.619 & 0.856 & $0.284-2.579$ & 0.783 \\
\hline \multicolumn{7}{|l|}{ Local-regional relapse } \\
\hline Yes vs. NO & 2.296 & $1.013-5.204$ & $0.047^{*}$ & 23.877 & $9.554-59.668$ & $0.000^{*}$ \\
\hline \multicolumn{7}{|l|}{ Metastasis } \\
\hline Yes vs. No & 9.085 & $1.871-44.128$ & $0.006^{*}$ & 5.045 & $1.195-21.288$ & $0.028^{*}$ \\
\hline \multicolumn{7}{|c|}{ WHO histological classification } \\
\hline NKUC vs. NKDC & 0.680 & $0.148-3.121$ & 0.620 & 0.580 & $0.129-2.609$ & 0.477 \\
\hline \multicolumn{7}{|l|}{ EA } \\
\hline$\leq 1: 10$ vs. $>1: 10$ & 0.568 & $0.234-1.381$ & 0.212 & 0.679 & $0.275-1.677$ & 0.401 \\
\hline \multicolumn{7}{|l|}{ VCA } \\
\hline$\leq 1: 40$ vs. $>1: 40$ & 0.613 & $0.207-1.816$ & 0.377 & 0.376 & $0.131-1.084$ & 0.070 \\
\hline \multicolumn{7}{|l|}{ |GFBP-1 } \\
\hline Low vs. High & 0.802 & $0.330-1.947$ & 0.626 & 0.520 & $0.213-1.267$ & 0.150 \\
\hline \multicolumn{7}{|l|}{ IGF-1 } \\
\hline Low vs. High & 1.649 & $0.612-4.443$ & 0.323 & 1.450 & $0.602-3.490$ & 0.407 \\
\hline \multicolumn{7}{|l|}{ IGFBP-1/IGF-1 } \\
\hline$>1$ vs. $\leq 1$ & 0.298 & $0.096-0.920$ & $0.035^{*}$ & 0.334 & $0.115-0.969$ & $0.044^{*}$ \\
\hline
\end{tabular}

tumorigenesis $[24,25]$; however, this effect was not observed in models of prostate cancer or osteosarcoma $[26,27]$. Furthermore, transgenic mice with modestly increased serum IGF-I levels did not show an increased onset or progression of breast tumorigenesis [28]. These results contradict a previous study showing that higher IGF-1 levels were associated with cancer mortality [16], but are consistent with our NPC study, suggesting that IGF-1 may play an important role in the development and progression of specific tumour types, such as NPC.

IGFBP-1 is a hepatocyte-derived secreted protein that undergoes various phosphorylation events and localizes to the nucleus and/or cytoplasm in hepatocellular carcinoma [29, 30]. In our study, however, IGFBP-1 was mainly observed within the nucleus of cancer cells and in the cytoplasm of normal cells, which is consistent with previous work showing nuclear localization of IGFBP $-2,-3-5$, and -6 in tumour cells $[29,30]$.
By binding and sequestering IGF-1, IGFBP-1 antagonized IGF-1 which could stimulate the proliferation of cancer cells [31]. However, accumulating evidence supports the idea that IGFBPs may drive cancer, rather than exert tumour suppressive functions in some tumour types. For example, IGFBP-2 induction has been shown to activate cell invasion, and increased levels of IGFBP-2 have been reported in ovarian tumour tissues and serum [21], as well as increased IGFBP-3 mRNA expression in HNSCC compared to healthy tissue [20]. In our study, an increased serum level of IGFBP-1 was detected in patients with NPC, which is consistent with findings observed for oral cancer [8], which suggests that IGFBP-1 may play a cancer-promoting role in NPC rather than a tumour-suppressing role.

Although clear evidence that tumour growth or migration is stimulated by IGFBP-1 is still lacking, IGFBP-1 has also been repored to have IGF-independent actions, such as activating $\alpha 5 \beta 1$ integrin [32]. Preclinical in vivo work 
has shown that deletion of IGFBP-I in the c-Myc transgenic mouse model resulted in decreased proliferation of prostatic tissue but had no effect on the development of prostate cancer [33]. Recently, one study showed that high expression levels of MMP9 and IGFBPs were associated with poor prognosis in patients with breast cancer [34]. In contrast, high expression of IGFBPs was associated with a favorable prognosis in patients with breast cancer when MMP9 was expressed at low levels. Their study suggests that in the presence of high MMP9 levels, IGFBP is digested, and then IGF is released and activates IGF signaling pathways that promote tumorigenesis in breast cancer. Because studies indicate that high levels of MMP9 expression are observed in most NPC tissues [35], the interaction between MMP9 and IGFBP-1 in NPC tumours may contribute to NPC patients with higher levels of IGFBP-1 and an unfavourable survival. While this represents an attractive hypothesis, the underlying mechanism remains unclear and should be investigated by further studies.

In addition, the balance between IGFs and IGFBPs may represent an important factor in tumour progression [23]. While higher levels of IGF-I and IGF-I/IGFBP-3 ratio are associated with an increased risk of death from breast cancer and CRC [36, 37], alternative findings have been observed in other studies. For example, elevated IGFBP-2 and reduced IGF-1 levels or high levels of an IGFBP-2/IGF-1 ratio were shown to stratify an ovarian cancer patient subgroup with poor prognosis [21]. Similar to this result, our study showed that a higher IGFBP-1/IGF-1 ratio predicts NPC patients with unfavourable survival. Our data indicate that IGFBP-1 may play a more important role in NPC progression than IGF-1.

Iwakiri et al. reported that EBV infections induce the expression of IGF-1 mRNA and support the growth of NPC-derived cell lines [15]. EBV latent membrane protein 1 (LMP1) selectively activates IGF1R by increasing IGF-1 expression and alters the phosphorylation of IGF1R, but not the expression [38]. However, increasing levels of IGF-1 have not been associated with EA or VCA-titre levels in NPC patients in our data, although the EBV-positive C666 cell lines were characterized by higher IGF-1 expression, which is in line with Iwakiri's findings regarding EBV-positive NPC cell lines [15], suggesting that the circulating levels of IGF-1 are inconsistent with IGF-1 expression after EBV infection in vitro. However, the increasing level of IGFBP-1 was associated with EA-positive, but not VCA-positive NPC sera, suggests that the association of EBV infection and the role of IGFs in NPC require further investigation.

Taken together, our study shows that higher serum IGFBP-1 levels and IGFBP-1/IGF-1 ratio correlate significantly with decreased overall survival in NPC patients. Further validation of these results is needed to determine the potential usefulness of these biomarkers for risk assessment.

\section{Conclusions}

Our data reveal that IGFBP-1 expression is upregulated in NPC cell lines and NPC tumour tissues and that IGFBP-1 serum levels are elevated in NPC patients. In addition, we showed that IGF-1 is more weakly expressed in NPC cell lines and tumour tissues and that decreasing serum levels of IGF-1 are observed in NPC patients. Furthermore, we observed that elevated serum levels of IGFBP-1 were significantly associated with shorter OS and RFS in NPC patients. Moreover, higher levels of IGFBP-1 and lower levels of IGF-1 were shown to predict worse outcome in NPC patients, suggesting that the ratio of serum IGFBP-1/IGF-1 represents a potential biomarker for NPC patient prognosis. These findings also highlight the more complex biological activities of IGFBP-1 and IGF-1 and reinforce the need to further clarify the role of the IGF system in NPC.

\section{Acknowledgments}

Not applicable.

\section{Funding}

This work was supported by the National Natural Science Foundation of China (No. 81472008).

\section{Availability of data and materials}

The datasets during and/or analysed during the current study available from the corresponding author on reasonable request.

\section{Authors' contributions}

GZ, WLL, and XWF contributed to the conception and design of the study, data acquisition, data analysis and manuscript writing. XWF participated in data acquisition and statistical analysis. SX participated in RT-PCR data collection, read and critical revision of the manuscript. JHL provided patient samples, clinical and laboratory data. All authors read and approved the final manuscript.

\section{Competing interests}

The authors declare that they have no competing interests.

\section{Consent for publication}

Not applicable.

\section{Ethics approval and consent to participate}

This study was approved by the Ethics Committee of Sun Yat-sen University Cancer Center. All patients and healthy volunteers in this study gave written consent, and all relevant investigations were performed according to the principles of the declaration of Helsinki.

\section{Author details}

'Department of Microbial and Biochemical Pharmacy, School of

Pharmaceutical Sciences, Sun Yat-sen University, No.132 Waihuandong Road, University Town, Guangzhou 510006, China. ${ }^{2}$ Department of Clinical

Laboratory Medicine, Sun Yat-sen University Cancer Center, Guangzhou, China.

Received: 30 October 2015 Accepted: 18 January 2017

Published online: 31 January 2017

\section{References}

1. Colaco RJ, Betts G, Donne A, Swindell R, Yap BK, Sykes AJ, Slevin NJ, Homer JJ, Lee LW. Nasopharyngeal carcinoma: a retrospective review of demographics, treatment and patient outcome in a single centre. Clin Oncol. 2013;25:171-7.

2. Yang Y, Yee D. Targeting insulin and insulin-like growth factor signaling in breast cancer. J Mammary Gland Biol Neoplasia. 2012;17:251-61.

3. Pollak M. The insulin and insulin-like growth factor receptor family in neoplasia: an update. Nat Rev Cancer. 2012;12:159-69. 
4. Gao Y, Katki H, Graubard B, Pollak M, Martin M, Tao Y, Schoen RE, Church T, Hayes RB, Greene MH, Berndt SI. Serum IGF1, IGF2 and IGFBP3 and risk of advanced colorectal adenoma. Int J Cancer. 2012;131:E105-13.

5. Christopoulos PF, Msaouel P, Koutsilieris M. The role of the insulin-like growth factor-1 system in breast cancer. Mol Cancer. 2015;14:43.

6. Wang Z, Wang Z, Liang Z, Liu J, Shi W, Bai P, Lin X, Magaye R, Zhao J. Expression and clinical significance of IGF-1, IGFBP-3, and IGFBP-7 in serum and lung cancer tissues from patients with non-small cell lung cancer. Onco Targets Ther. 2013;6:1437-44.

7. Sharma J, Gray KP, Evan C, Nakabayashi M, Fichorova R, Rider J, Mucci L, Kantoff PW, Sweeney CJ. Elevated insulin-like growth factor binding protein1 (IGFBP-1) in men with metastatic prostate cancer starting androgen deprivation therapy (ADT) is associated with shorter time to castration resistance and overall survival. Prostate. 2014;74:225-34.

8. Brady G, O'Regan E, Miller I, Ogungbowale A, Kapas S, Crean SJ. Serum levels of insulin-like growth factors (IGFs) and their binding proteins (IGFBPs), $-1,-2,-3$, in oral cancer. Int J Oral Maxillofac Surg. 2007:36:259-62.

9. Neuhouser ML, Platz EA, Till C, Tangen CM, Goodman PJ, Kristal A, Parnes HL, Tao Y, Figg WD, Lucia MS. Insulin-like growth factors and insulin-like growth factor-binding proteins and prostate cancer risk: results from the prostate cancer prevention trial. Cancer Prev Res. 2013;6:91-9.

10. Šunderić M, Malenković V, Nedić O. Complexes between insulin-like growth factor binding proteins and alpha-2-macroglobulin in patients with tumor. Exp Mol Pathol. 2015;98:173-7.

11. Wolpin BM, Michaud DS, Giovannucci EL, Schernhammer ES, Stampfer MJ, Manson JE, Cochrane BB, Rohan TE, Ma J, Pollak MN, Fuchs CS. Circulating insulin-like growth factor binding protein-1 and the risk of pancreatic cancer. Cancer Res. 2007;67:7923-8.

12. Wolpin BM, Meyerhardt JA, Chan AT, Ng K, Chan JA, Wu K, Pollak MN, Giovannucci EL, Fuchs CS. Insulin, the insulin-like growth factor axis, and mortality in patients with nonmetastatic colorectal cancer. J Clin Oncol. 2009;27:176-85

13. Lukanova A, Zeleniuch-Jacquotte A, Lundin E, Micheli A, Arslan AA, Rinaldi S, Muti P, Lenner P, Koenig KL, Biessy C. Prediagnostic levels of C-peptide, IGF-I, IGFBP $-1,-2$ and -3 and risk of endometrial cancer. Int I Cancer. 2004;108:262-8.

14. Singh $P$, Alex JM, Bast F. Insulin receptor (IR) and insulin-like growth factor receptor 1 (IGF-1R) signaling systems: novel treatment strategies for cancer. Med Oncol. 2014;31:805.

15. Iwakiri D, Sheen TS, Chen JY, Huang DP, Takada K. Epstein-Barr virus-encoded small RNA induces insulin-like growth factor 1 and supports growth of nasopharyngeal carcinoma-derived cell lines. Oncogene. 2005;24:1767-73.

16. Kushlinskii NE, Gershtein ES, Nikolaev AA, Delektorskaya W, Korotkova EA, Dvorova EK, Kostyleva Ol. Insulin-like growth factors (IGF), IGF-binding proteins (IGFBP), and vascular endothelial growth factor (VEGF) in blood serum of patients with colorectal cancer. Bull Exp Biol Med. 2014;156:684-8.

17. Cao Y, Nimptsch K, Shui IM, Platz EA, Wu K, Pollak MN, Kenfield SA, Stampfer MJ, Giovannucci EL. Prediagnostic plasma IGFBP-1, IGF-1 and risk of prostate cancer. Int J Cancer. 2015;136:2418-26.

18. Patel D, Ellis R, Howard B, Boufraqech M, Gara SK, Zhang L, Quezado MM, Nilubol N, Kebebew E. Analysis of IGF and IGFBP as prognostic serum biomarkers for adrenocortical carcinoma. Ann Surg Oncol. 2014;21:3541-7.

19. Imsumran A, Adachi Y, Yamamoto H, Li R, Wang Y, Min Y, Piao W, Nosho K, Arimura $Y$, Shinomura $Y$. Insulin-like growth factor-l receptor as a marker for prognosis and a therapeutic target in human esophageal squamous cell carcinoma. Carcinogenesi. 2007;28:947-56.

20. Zhi X, Lamperska K, Golusinski P, Schork NJ, Luczewski L, Golusinski W, Masternak MM. Expression levels of insulin-like growth factors 1 and 2 in head and neck squamous cell carcinoma. Growth Horm IGF Res. 2014;24:137-41.

21. Huang YF, Cheng WF, Wu YP, Cheng YM, Hsu KF, Chou CY. Circulating IGF system and treatment outcome in epithelial ovarian cancer. Endocr Relat Cancer. 2014;21:217-29.

22. Hass $\mathrm{H}$, Jobst J, Scheurlen M, Vogel U, Nehls O. Gene expression analysis for evaluation of potential biomarkers in hepatocellular carcinoma. Anticancer Res. 2015;35:2021-8.

23. Samani AA, Yakar S, LeRoith D, Brodt P. The role of the IGF system in cancer growth and metastasis: overview and recent insights. Endocr Rev. 2007;28:20-47.

24. Wu Y, Yakar S, Zhao L, Hennighausen L, LeRoith D. Circulating insulin-like growth factor- levels regulate colon cancer growth and metastasis. Cancer Res. 2002;62:1030-5.
25. Wu Y, Cui K, Miyoshi K, Hennighausen L, Green JE, Setser J, LeRoith D, Yakar S. Reduced circulating insulin-like growth factor I levels delay the onset of chemically and genetically induced mammary tumors. Cancer Res. 2003;63: 4384-8.

26. Anzo M, Cobb L, Hwang DL, Mehta H, Said JW, Yakar S, LeRoith D, Cohen P. Targeted deletion of hepatic lgf1 in TRAMP mice leads to dramatic alterations in the circulating insulin-like growth factor axis but does not reduce tumor progression. Cancer Res. 2008;68:3342-9.

27. Hong SH, Briggs J, Newman R, Hoffman K, Mendoza A, LeRoith D, Helman L, Yakar S, Khanna C. Murine osteosarcoma primary tumour growth and metastatic progression is maintained after marked suppression of serum insulin-like growth factor I. Int J Cancer. 2009;124:2042-9.

28. Dearth RK, Kuiatse I, Wang YF, Liao L, Hilsenbeck SG, Brown PH, Xu J, Lee AV. A moderate elevation of circulating levels of IGF-I does not alter ErbB2 induced mammary tumorigenesis. BMC Cancer. 2011;11:377.

29. Zhou DS, Wang HB, Zhou ZG, Zhang YJ, Zhong Q, Xu L, Huang YH, Yeung SC, Chen MS, Zeng MS. TACC3 promotes stemness and is a potential therapeutic target in hepatocellular carcinoma. Oncotarget. 2015;6:24163-77.

30. Liu ZH, Hu JL, Liang JZ, Zhou AJ, Li MZ, Yan SM, Zhang X, Gao S, Chen L, Zhong $\mathrm{Q}$, Zeng MS. Far upstream element-binding protein 1 is a prognostic biomarker and promotes nasopharyngeal carcinoma progression. Cell Death Dis. 2015;6:e1920.

31. Firth SM, Baxter RC. Cellular actions of the insulin-like growth factor binding proteins. Endocr Rev. 2002;23:824-54.

32. Jones JI, Gockerman A, Busby WJ, Wright G, Clemmons DR. Insulin-like growth factor binding protein 1 stimulates cell migration and binds to the alpha 5 beta 1 integrin by means of its Arg-Gly-Asp sequence. Proc Natl Acad Sci U S A. 1993;90:10553-7.

33. Gray A, Aronson WJ, Barnard RJ, Mehta H, Wan J, Said J, Cohen P, Galet C. Global Igfbp1 deletion does not affect prostate cancer development in a cMyc transgenic mouse model. J Endocrinol. 2011;211:297-304.

34. Park JH, Rasch MG, Qiu J, Lund IK, Egeblad M. Presence of insulin-like growth factor binding proteins correlates with tumor-promoting effects of matrix metalloproteinase 9 in breast cancer. Neoplasia. 2015;17:421-33.

35. Liu Z, Li L, Yang Z, Luo W, Li X, Yang H, Yao K, Wu B, Fang W. Increased expression of MMP9 is correlated with poor prognosis of nasopharyngeal carcinoma. BMC Cancer. 2010:10:270.

36. Duggan C, Wang CY, Neuhouser ML, Xiao L, Smith AW, Reding KW, Baumgartner RN, Baumgartner KB, Bernstein L, Ballard-Barbash R, McTiernan A. Associations of insulin-like growth factor and insulin-like growth factor binding protein-3 with mortality in women with breast cancer. Int J Cancer. 2013;132:1191-200.

37. Jiang B, Zhang X, Du LL, Wang Y, Liu DB, Han CZ, Jing JX, Zhao XW, Xu XQ. Possible roles of insulin, IGF-1 and IGFBPs in initiation and progression of colorectal cancer. World J Gastroenterol. 2014;20:1608-13.

38. Tworkoski K, Raab-Traub N. LMP1 promotes expression of insulin-like growth factor 1 (IGF1) to selectively activate IGF1 receptor and drive cell proliferation. J Virol. 2015;89:2590-602.

\section{Submit your next manuscript to BioMed Central and we will help you at every step:}

- We accept pre-submission inquiries

- Our selector tool helps you to find the most relevant journal

- We provide round the clock customer support

- Convenient online submission

- Thorough peer review

- Inclusion in PubMed and all major indexing services

- Maximum visibility for your research

Submit your manuscript at www.biomedcentral.com/submit 